To cite this article: Shehu Umar Mabera (2020) Implications of Poor Management of Students' Academic Records in Nigerian Universities. Information Impact: Journal of Information and Knowledge Management, 11:3, 31-40,DOI: dx.doi.org/10.4314/iijikm.v11i3.4

To link to this article: https://dx.doi.org/10.4314/iijikm.v11i3.4

\title{
Implications of Poor Management of Students' Academic Records in Nigerian Universities
}

\author{
Shehu Umar Mabera \\ Abdullahi Fodiyo Library, Usmanu Danfodiyo University, Sokoto
}

\begin{abstract}
This study assessed students' perceived implications of poor management of students' academic records in Nigerian universities. The study followed the single case study and was conducted at the Usmanu Danfodiyo University, Sokoto (UDUS). The population of the study comprised of 5905 final year students from eleven faculties of the University in 2018/2019 session. Data was collected by means of a questionnaire. Simple random sampling technique was used to select 361respondents. 320 representing $85 \%$ responded. The data collected were analysed using mean and standard deviation to find answers to the research questions. From the analyses it was established that delays in decision making, in graduating students, as well as loosing opportunities by the students were identified as part of the implications of poor management of the students' academic records. The managements of the UDUS should consider the findings of the study and address these malaises for proper record management and the associated benefits.
\end{abstract}

Keywords Students' Records, Academic Record, Poor Records Management, University

CONTACT Shehu Umar Mabera Shehu.umabera@udusok.edu.ng Abdullahi Fodiyo Library, Usmanu Danfodiyo University, Sokoto 2020 The Author Published with License by Information Impact 


\section{Introduction}

The educational life cycle of a student and his relationship with the university may never end bearing in mind that even after graduation, the students may come back to the University to request for some relevant academic documents either to further their education or for referee note (Adade, Dampson, Quashigah \& Eshun, 2018). The records that establish the students' relationship with the university can be categorized into 'current' or 'semi-current' records. While students remain at the University, their records are considered to be 'current'. Once the students departed, their records become 'semi-current'. The semicurrent records will gradually be transferred into non-current, which will eventually end up either being destroyed or permanently preserved in the University records center or archive.

The Joint Information Systems Committee (JISC) (2007 as cited in Mabera, 2015) categorized students' records into three broad categories. First categories of students' records are those, which provide relationship between the student and the institution such as admission and enrolment, payment of tuition fees and academic disciplinary proceedings. Second categories of student's records documents student as a learner, for example program undertaken, academic progress and performance awards. Third categories of the students' records are about the student as individual and consumer of the services provided by the institution, such as accommodation, counselling, library and IT support services.

According to JISC (2007, as cited in Mabera, 2015), most records in category 1 and 3 have specific retention periods triggered by formal end of a student's direct relationship with university, although the information they contain may be aggregated and analysed to support the university's planning and development activities. A university will need to retain some of the records in category 2 to provide confirmatory information to potential employers, professional bodies and associations, and bodies which regulate entry into i.e. medical profession or to address a contentious issue (Mabera, 2015). Adade, Dampson, Quashigah and Eshun (2018) supported this assertion where they stated that whenever there is contentious issue over certificates awarded to students, one easiest way to perhaps calm down nerves and establish the accuracy and authenticity of such documents is to refer to the university's academic records archive for verification and confirmation. Academic records management occupies a strategic position in the efficient and effective management of students' records in the university administration (Seniwoliba, Mahama \& Abilla, 2017). It is central in ensuring the credibility of students' records, because proper records management (RM) always proves very relevant in terms of providing accurate students records for verification and confirmation in times of disputes. Based on this affirmation, therefore, effective management of the academic records in the University is paramount. Universities must ensure that academic records are properly documented and secured. Good RM ensures that an institution meets its records keeping requirements by ensuring that it captures and preserves the evidence required to establish its activities and existence (Adu-Oppong \& Asante, 2014).

Nwaomah (2015) emphasized that "effective management of students' records can ensure an advantage of one university over another, enable a seamless access and controlled access to students data simultaneously by different arms of a university and also protects a university from student's fraud" (p. 30). The survey by Joy and Agala (2019) identified effective records management as part of the strategies for ensuring quality assurance in the management of university education in Nigeria. Conversely, poor RM may have a number of effects on day-to-day operation of the University. It may cause universities to lose a wealth of knowledge produced by its employees during daily operation; universities may also lose part or all of their corporate memory; records documenting the development of functions and data on 
research carried out may be destroyed or misplaced (Tagbotor, Adzido \& Agbanu, 2015). The authors further stated that, surviving material may be without order and control, thus losing its value as evidence and resulting in over-dependence on individual memory. Such lack of control results in loss of accountability for an organization's actions. According to Federal Ministry of Education (2004) in most cases, misplaced or lost records delay necessary actions on urgent matters, or lead to irrational decisions, which may translate to social crisis or embarrassment to the university system. In 2012 the National Universities Commission (NUC) had once suspended the operating licenses of seven private universities in Nigeria for reasons ranging from non-compliance with its regulations, poor management of academic activities and mismanagement of students' examination records (Nwaomah, 2015).

Despite the importance of records in the day-to-day running of universities in Nigeria, RM has been compromised. Accurate, comprehensive and trustworthy records that provide information about university's operation and services are often created but are not properly managed. Instead, handful of setbacks are recorded in terms of improper security of records, inadequate resource, incompetent personnel, use of manual system in recording and storing of information and negative attitude of staff towards record keeping (Allison \& Otuza, 2017). Lot of students suffered in the hands of many universities owing to poor RM in terms of credentials, exam scripts, results and the like. It has also added years to the students' maximum mandate with the institution. This unpleasant situation is not only deterrent to the student but also to the university as it has resulted to litigation in some cases (Allison \& Otuza, 2017). For example, Taylor (2000 as cited in Allison \& Otuza, 2017) reported that a former student of University of Durban-Westville made a court application demanding to see his examination scripts. This case demonstrates the possible consequence of not providing information timeously.

Nwankwo (2001 as cited in Akor \& Udensi, 2013) observed that tertiary institutions in Nigerian have an information generation capacity of $76 \%$ and a utilization of $3 \%$. This gap is a huge point to worry about (Allison \& Otuza, 2017). This amount to the inability of most educational institutions to put up sound RM practices. Studies have identified many problems in RM in Nigerian universities from the perspective of the main stakeholders (university management, the staff and the students) of the universities (Asogwa, 2013; Abdulrahman, 2015; Allison \& Otuza, 2017, Ojo, Mairiga, Idakwo \& Song (2019). It however, appears that there is the paucity of information regarding the implications of poor management of students' academic records in Nigerian universities. This knowledge void is considered as a problem worthy of empirical investigation in the country. In view of this, the current study sought to fill the identified gap by providing answers to the following research questions.

\section{Research questions}

In order to achieve success in the study, two research questions are posed to guide the study.

1. What are the students' perceived implications of poor management of the students' academic records in the university?

2. What are the students' perceived causes of poor management of the students' academic records in the university? 


\section{Literature review}

A number of studies in the recent past were carried out to find out the way and manner students' records are being handled and managed in Nigerian universities. Some of the surveys in this context are reviewed. Nakpodia (2011) surveyed challenges associated with students' records management in some selected federal, state and private universities in Nigeria. The result revealed lack of government policy, lack of skilled manpower with necessary competence in RM, delay in records retrieval and security as part of the challenges associated with students' records management. Delay in records retrieval is not only affecting the individual student, the university but also the nation as well (Onwudebelu, Fasola \& Williams, 2013). The authors gave example of an engineering student who wants to improve his engineering skills and profile so that he would be more able and capable of increasing the nation's engineering output will be denied and frustrated by transcript delays. The authors further submitted that it is indeed a nightmare of unimaginable proportions to make an attempt to get academic records from some universities, especially in recent times due to poor records management practices.

Allison and Otuza (2017) in their study pointed out factors such as: inadequate number of staff in the registry with RM qualification or with related courses; negative attitude of staff; badly implemented record management system; insecurity of the records; absence of training; inadequate computer terminals and resources to ineffective retrieving; lack of retention and disposition schedule; as well as lack of policy and filing procedure manual as factors that hinder the effective management of students' records in Babcock University, Nigeria. In a related study Barde, Shaibu and Daudu (2019) found that retrieval of students' academic records in Ahmadu Bello University was slow and time consuming due to poor records organization. The implications of these challenges are difficulties in administering, development and supervision of educational systems (Amanchukwu \& Ololube, 2015), delay in graduating students (Mabera, 2015). Chiwanza and Mutongi (2016) identified number of implications of not having proper records management in higher institution of learning such as: failure to have history of the organisation; fading away of institutional memory; arbitrary decision making; repetition of tasks which leads to waste of resources and time; failure to provide accurate student results; unable to trace students records if they come for reference years later; unable to reconstruct after a disaster etc. Other implications are difficulties in accounting for any decisions taken (Nyathi \& Peterson, 2017), delay in decision making, overlapping of authority and responsibility among human resource and registry staff (Nkebukwa, 2019), loss of institutional memories (Netshakhuma, 2019).

The implications of poor records management also affected universities quest for better international ranking. Muhammad, Isa, Samsudin and Miah (2020) stated that universities in Nigeria aspire to be on the global map with better international rankings. Regrettably, they are overwhelmed with inefficient administration and management due to poor management of records and information. From the review of the literature it appears that academic records management in Nigerian universities is not given the proper treatment. The picture is dejected; the records are being kept without proper care, no RM strategies, no adequate funding, there is lack of top management commitment towards RM, lack of training programme for staff handling university records. This suggests that students' academic records are not adequately managed as a result the Universities as well as the students may suffer some consequences. The literature reviewed has shown clearly that there is a gap to be filled. The gap arises because from the available literature none specifically reported on the poor management of students' 
academic records from the students' perception, hence, the need for this research. The study provides a valuable contribution to the existing body of knowledge on the subject of records management.

\section{Methodology}

The work adopted a case study research because the researcher based the investigation on a single university (UDUS). The study population consisted of 5,905 final year (second semester) students across 11 faculties of UDUS in 2018/2019 session. The faculties are Agriculture $=245$, Arts \& Islamic Studies $=567$, Clinical Sciences $=42$, Education \& Extension Services $=1,479$, Law $=175$, Management Science $=440$, Medical Laboratory Sciences $=83$, Pharmaceutical Sciences $=101$, Science $=2,169$, Social Sciences $=485$, and Veterinary Medicine $=119$. Yamane's (1967) formula for calculating sample size was used in determining the sample size.

$$
n=\frac{N}{1+N(e)^{2}}
$$

where $\mathrm{n}=$ sample size, $\mathrm{N}=$ population, $\mathrm{e}=$ error tolerance. The formula was further used in determining the representative proportion from each faculty. Thus, total samples of 376 students were subsequently selected using simple random sampling technique. The questionnaire was used for data collection and was structured on a four points rating scale. The questionnaires were administered by the researcher to the sample in their respective faculties. Data was collected within a period of three weeks. A total of 320 filled in questionnaires were received back and all are found valid for analysis, giving a response rate of $85 \%$. The data was captured onto the computer via SPSS version 20. For the purpose of decision making a mean scores of 2.50 and above were considered, mean scores below 2.50 were rejected.

\section{Results}

Research Question One: What are the students' perceived implications of poor management of the students' academic records in the university?

Table 1: Mean scores and standard deviation of the perception of students' on the implications of poor management of the students' academic records in the university

\begin{tabular}{llllll}
\hline S/N & \multicolumn{1}{c}{ ITEMS } & N & M & SD & Decision \\
\hline 1 & Delay in decision making & 320 & 3.08 & 1.535 & Agreed \\
2 & Delay in graduating students & 320 & 4.62 & 0.675 & Agreed \\
3 & Delay in NYSC mobilization & 320 & 4.43 & 0.748 & Agreed \\
4 & Carryover/spillover course(s) by the students & 320 & 3.83 & 1.149 & Agreed \\
5 & Repeating a year by the students & 320 & 3.04 & 1.529 & Agreed \\
6 & Loosing opportunities by the students & 320 & 4.37 & 0.663 & Agreed \\
\hline
\end{tabular}

The result presented in Table1 indicated that all items regarding students' perceived implications of poor management of the students' academic records in the university are accepted as indicated by their high mean, which are 3.00 and above. The standard deviation ranged from 0.663 to 1.535 indicating that the respondents were not far from each other in their responses and agreement with the items. Delay in graduating students appears to be the most perceived implication with mean scores of 4.62. Respondents perceived delay in decision making as the least perceived implication with a mean score of 3.08. 


\section{Research Question Two: What are the students' perceived causes of poor management of the} students' academic records in the university?

Table 2: Mean rating of the perception of students' perceived causes of poor management of the students' academic records in the university

\begin{tabular}{llllll}
\hline S/N & \multicolumn{1}{c}{ ITEMS } & N & M & SD & Decision \\
\hline 1 & Absence of records management policy & 320 & 3.41 & 1.350 & Agreed \\
2 & Poor attitude towards records management & 320 & 4.05 & 1.025 & Agreed \\
3 & Lack of storage facilities for academic records & 320 & 4.51 & 0.704 & Agreed \\
4 & Lack of computers for electronic records management & 320 & 4.11 & 1.003 & Agreed \\
5 & Loss of data due to computer breakdown or virus attack & 320 & 4.07 & 1.068 & Agreed \\
6 & Wrong data entry & 320 & 4.53 & 0.733 & Agreed \\
7 & Improper security for records & 320 & 3.02 & 1.528 & Agreed \\
8 & Lack of training for staff maintaining the records & 320 & 3.16 & 1.528 & Agreed \\
\hline
\end{tabular}

The result presented in Table 2 show that all items regarding students' perceived causes of poor management of the students' academic records in the university are accepted as indicated by their high mean, which are 3.00 and above. These indicate the acceptability of those items as causes of poor management of the students' academic records in the university. The standard deviation ranged from 0.704 to 1.528 indicating that the respondents were not far from each other in their responses and agreement with the items. Wrong data entry appears to be the most perceived cause of poor management of the students' academic records in the university with mean scores of 4.53. Respondents perceived improper security for records as the least cause of poor management of the students' academic records with a mean score of 3.02 .

\section{Discussion of findings}

From the analyses of the data it is clear that the respondents accepted all the items in the questionnaire related to both implications and causes of poor management of the students' academic records in the studied university. Poor management of the students' academic records in the university had far reaching implications in the day-to-day administration of the university especially on the tenure of the students and even after their graduation. From table 1 it is clear that the respondents agreed that poor management of the students' academic records could lead to delay in decision making, delay in graduating students and delay in NYSC mobilization. Decision making is one of the top management functions in the university and every decision taken needs to be backed with evidence. Timely use of students' academic records in solving problems and taking far-reaching decisions will speed graduation of students, NYSC mobilization, reduced problems of carryover and spillover in Nigerian universities (Mabera, 2015). Every year, hundreds of students are graduating from the university, however, those whose records are lost or not found, their graduation may be delayed depending on when a student's records was discovered lost or missing. There are times when graduating students may be delayed by a semester or two. This may seem disappointing to students and or their families.

Delay in NYSC mobilization is yet another implication perceived by the students. Every student that successfully completed his/her prescribed years of study and is within the prescribed years of service is normally mobilized to undergo mandatory one year NYSC programme in any state of the federation. However, this is only tenable where proper academic records are maintained, where it is not, the prospective corps members will be delayed. Another implication identified by the students in the university studied is carrying over and spillover of some course(s) by the students. Where proper 
academic records are not maintained, some of the students' academic records may be lost or destroyed consequence upon which the affected student may have to carryover or spillover course(s) that are affected in subsequent year.

The respondents equally identified that with poor RM in the university, a number of students may have to repeat a year or so before graduation from the university. For most students, this creates a sense of frustration and boredom from repeating similar tasks and assignment (Alexander, Entwistle \& Dauber, 1994). This also confirmed Allison and Otuzu (2017) position that poor management of the students' records has added more years to the students' maximum mandate with the institution. This means that students have to stay extra more year(s) beyond the normal stipulated years. The analyses also indicated loosing opportunities by the students. Students are likely to lose some opportunities when certain academic records could not be produced when demanded. These opportunities may be scholarship, job opportunities or admission into higher degrees. Losing opportunities by students as a result of poor RM has also been confirmed by Onwudebelu, Fasola and Williams (2013) who advanced that unfortunately, the emotional and economic cost of this challenge is rather incalculable: lost opportunities for further studies and good employment to mention just two. The authors lamented that many prospective graduate students have lost admission opportunities within and outside Nigeria as a result of their inability to obtain their transcripts to support their applications on time.

The second research finding of the study showed that the mean scores of all the items are above 2.50 of the mean criterion. This implies that the respondents that are included in this study agreed that there are negative factors associated with efficient management of students' academic records in the UDUS. From table 2 it is clear that the respondents perceived absence of records management policy, poor attitude towards records management, lack of storage facilities for academic records, lack of computers for electronic records management, loss of data due to computer breakdown or virus attack, wrong data entry, lack of training for staff maintaining the records, and improper security for records as causes of poor management of students' academic records in the university. The findings confirm the findings of previous researches (Nakpodia, 2011; Akor \& Udensi, 2013; Allison \& Otuza, 2017; Adade, Dampson, Quashigah \& Eshun, 2018). These challenges might prevent the university from enjoying the benefits of proper RM such as effective planning; supervision and monitoring of programmes; proper assessment of student's performance and needs; better improvement in instructional facilities for teaching and learning, identified by researchers ( Azameti \& Adjei, 2013; Asogwa, 2013; Okoli \& Onuigbo, 2014; Out, Bempah, \& Amoako-Ohene, 2014; Kavuta \& Nyamanga, 2018) in previous studies.

\section{Conclusion and recommendations}

The aim of the research has been achieved in the survey. Poor management of students' academic record in UDUS has some far reaching implications on students during and even after their tenure from the university. The implications include delay in decision making; delay in graduating students; delay in NYSC mobilization; carryover or spillover; repeat; and loosing opportunities by the students. The causes of the poor management of students' academic record in the university were also established as perceived by the respondents in the study. The causes are lack of records management policy; poor attitude towards records management, lack of storage facilities for academic records, lack of computers for electronic records management, loss of data due to computer breakdown or virus attack, lack of training for staff 
maintaining the records and improper security for records as causes of poor management of students' academic records in the university.

In the light of the foregoing conclusions, the following recommendations are made:

- The management of the university should ensure that all their records are properly managed and secured.

- The university needs to develop policies that will guide the creation, management and use of its records.

- The university should also deploy modern technologies such as Electronic Records Management System (ERMS) in managing the records. The practice of RM need to be changed as the new technologies also evolve and which means our way of storing and retrieving records in the past must change in accordance with technology today.

- Staff involved in handling students' records should be properly trained; in addition the university should raise the awareness of the university staff on the importance of good recordkeeping in the university. Nguyen, et al. (as cited in Marutha \& Ngulube 2018) underscores the importance of top management support, good recordkeeping awareness and practice, adequate and on-going training and support as bases for good records management practices.

- The university should note that establishing an effective RM program will enhance accurate retrieval and timely availability of records required and this would reduce common problems of management in universities, such as inability to forward students' reports/records or release results on schedule (Nwankwo as cited in Atulomah, 2011).

\section{References}

Abdulrahman, A. B. (2015). Management of university records for effective administration of universities in North Central Nigeria. International Journal of Library and Information Science, 7(3), 47 - 54.

Adade, A., Dampson, D. G., Quashigah, A.Y. \& Eshun, P. (2018). Academic records management in Ghanaian basic schools: A study of basic schools in the Ashiedu Keteke Sub-metro in the greater Accra Region. British Journal of Education, 6 (4), 33 - 49.

Adu-Oppong, A. A. \& Asante, O. (2014). An examination of records management at the College of Technology Education, Kumasi. International Journal of Educational Development, 2(14), $171-183$.

Akor, P. U. \& Udensi, J. (2013). An assessment of record management system in establishment division of two universities in Nigeria. International Letters of Social and Humanistic Sciences, 13, $97-$ 109 doi:10.18052/www.scipress.com/ILSHS.13.97.

Alexander, K. L., Entwistle, D. R. \& Dauber, S. L. (1994). On the success of failure: A reassessment of the effects of retention in the primary grade. New York: Cambridge University.

Allison, G. O. \& Otuza, C. E. (2017). Militating factors on the efficient management of students' record among registry staff in academic institutions (A case study of Babcock University). Advances in Social Sciences Research Journal, 4(18), 21-34. 
Amanchukwu, R. N. \& Ololube, N. P. (2015). Excellent school records behaviour for effective management of educational systems. Human Resource Management Research, 5(1), 12 - 17 DOI: 10.5923/j.hrmr.20150501.02.

Asogwa, B. E. (2013). The readiness of universities in managing electronic records: A study of three federal universities in Nigeria. The Electronic Library, 31(6), 792 - 807.

Atulomah, B. C. (2011). Perceived records management practice and decision making among university administrators in Nigeria. Library Philosophy and Practice (e-journal). 541.http://digitalcommons.unl.edu/libphilprac/541.

Azameti, M. S. K., \& Adjei, E. (2013). Challenges in academic records management in tertiary institutions in Ghana. International Journal of Scientific Research in Education, 6(3), 287 296.

Barde M. A., Shaibu, B. A. \& Daudu, H.M.(2019). Organization and retrieval of students' academic records in Ahmadu Bello University, Zaria - Nigeria. Samaru Journal of Information Studies, 19(1), 1-13

Chiwanza, K. \& Mutongi, C. (2016). Managing quality through records management in open and distance learning institutions. The International Journal of Engineering and Science (IJES), 5(12), 63-70.

Federal Ministry of Education (FME) (2004). The status of university education in Nigeria. The technical reports, 54, $41-80$.

Joy, N. C. \& Agala, H.O. (2019). Quality assurance in the management of Nigeria university education. Advances in Social Sciences Research Journal, 6(8), 240 - 247.

Kavuta, K. D. \& Nyamanga, S. (2018). The factors affecting the implementation of students' records management system to higher learning institutions in Tanzania a case of the institute of accountancy Arusha. International Journal of Scientific \& Technology Research, 7(2), 150 - 156.

Mabera, S. U. (2015). Management of students' academic records in federal universities in North West Nigeria: Implication for access and utilization. Information Trends, 13, $24-34$.

Marutha, N, S. \& Ngulube, P. (2018). Enterprise content management system implementation readiness to improve medical records management in Limpopo province, South Africa. Library Philosophy and Practice (e-journal), 1769.

Muhammad, J. S., Isa, A.M., Samsudin, A. Z. H. \& Miah, S. J. (2020). Critical factors for implementing effective information governance in Nigerian universities: A case study investigation. Education and Information Technology. https://doi.org/10.1007/s10639-020-10206-3.

Nakpodia, E. D. (2011). Student's records: Challenges in the management of student personnel in Nigerian tertiary institutions. Prime Research on Education (PRE), 1(3), 044 - 049.

Netshakhuma, N. S. (2019). Assessment of the management of student affairs records: Case of the University of Mpumalanga in South Africa. Records Management Journal, 30(1), 23 42 https://doi.org/10.1108/RMJ-01-2019-0004.

Nkebukwa, L. L. (2019). Challenges and prospects of record management practice in higher learning institutions in Tanzania: A case of college of business education (CBE). Sky Journal of Educational Research, 4(4), 043 - 047. 
Nwaomah, A. E. (2015). Political factors' influence on students' records management effectiveness in the Nigerian university system. European Journal of Research and Reflection in Management Sciences, 3(2), $29-41$.

Nyathi, T. \& Peterson, D. (2017). Towards implementing a records management policy at the National University of Science and Technology. ESARBICA Journal: Journal of the East and South Africa Regional Branch of the International Council on Archives, 36, 12 - 28.

Ojo, J. O., Mairiga, H. M., Idakwo, I. S. \& Song, U. M. (2019). Policy guidelines for records management in Nigerian university libraries. Covenant Journal of Library \& Information Science (CJLIS), 2(2), 1-15.

Okoli, B. E. \& Onuigbo, F. N. (2014). Impact of records keeping on office managers' efficiency in Nigerian universities. International Journal of Education Learning and Development, 2(3), 25 -31 .

Onwudebelu, U., Fasola, S. \& Williams, E. O. (2013). Creating pathway for enhancing student collection of academic records in Nigeria - A new direction. Computer Science and Information Technology, 1(1), 65-71 doi: 10.13189/csit.2013.010108.

Out, B. O., Bempah, O. A. \& Amoako-Ohene, K. (2014). Management of students' records at Koforidua Polytechnic: Implications for good governance. Information and Knowledge Management, 4(11), 69 - 74.

Seniwoliba, A. J., Mahama, A. V. and Abilla, B. J. (2017). Challenges of records management in higher education in Ghana: The case of University for Development Studies. International Journal of Educational Policy Research and Review, 4 (3), 29 - 41 https://doi.org/10.15739/IJEPRR.17.005.

Tagbotor, D. P., Adzido, R. Y. N. \& Agbanu, P. G. (2015). Analysis of records management and organizational performance. International Journal of Academic Research in Accounting, Finance and Management Sciences, 5(2), 1-16.

Yamane, Taro. (1967). Statistics: An introductory analysis, $2^{\text {nd }}$ ed. New York: Harper and Row. 